\title{
Comparative Effects of Ethanol Leaf-Extracts of Vernonia Amygdalina and Azadirachta Indica on Catalases and Reduced Glutathione in Albino Rats
}

\author{
Offor, C.E. \\ Department of Biochemistry, Ebonyi state university, Abakaliki, Nigeria
}

\begin{abstract}
The comparative effects of ethanol leaf-extracts of Vernonia amygdalina and Azadirachta indica on catalases and reduced glutathione in albino rats were conducted through spectrophotometric methods. The animals were grouped into seven ( $A, B, C, D, E, F$ and $G)$ containing six albino rats each. The leaf-extract of Azadirachta indica at 200, 400 and $600 \mathrm{mg} / \mathrm{kg}$ body weights was administered for two weeks to animals in groups $A, B$ and $C$ respectively, with corresponding concentrations of Vernonia amygdalina extract given to animals in groups $D, E$, and $F$ through oral intubation, while those in group $G$ (control) received $0 \mathrm{mg} / \mathrm{kg}$ body weight of the extract. Blood samples were collected on the fifteenth day following the last day of administration. The serum catalase activities (u/mg of protein) for the groups that received leaf-extracts of Azadirachta indica and Vernonia amygdalina were reduced significantly $(p<0.05)$ at $600 \mathrm{mg} / \mathrm{kg}$ as they recorded $3.07 \pm 0.185$ and $2.53 \pm 0.256$ respectively while the control group gave $6.11 \pm 0.149$. At $200 \mathrm{mg} / \mathrm{kg}$, the extract from Azadirachta indica did not show any significant $(p>0.05)$ increase while that of Vernonia amygdalina showed significantly $(p<0.05)$ greater elevations of reduced glutathione concentrations at all the stipulated doses. The extract from Azadirachta indica reduced the catalase activities significantly at 400 and $600 \mathrm{mg} / \mathrm{kg}$ body weight, while that of Vernonia amygdalina significantly reduced the catalase activities at all the stipulated doses. The results showed that the extract of Vernonia amygdalina was more effective as an anti-oxidant agent than Azadirachta indica extract.
\end{abstract}

Key words: Vernonia amygdalina, Azadirachta indica, catalases, reduced glutathione, albino rats

\section{Introduction}

The retention of medicinal practices and traditions is evident mainly in the rural communities. With modern technology, medicine has moved from a purely traditional phase to high technological production of synthetic chemical and the extraction of chemicals from plants to produce drugs. Several of these drugs are derived from plants that form the basis of traditional medicine (Bergman, 2000). Therefore, medicinal plants are plants that contain medicinal products as their active ingredients. Medicinal plants are used commercially in modern medicine and pharmacology (Andrews and Fatt, 2002).

Azadirachta indica (neem) is a tree in the mahogany family. It is one of the species in the genus "Azadirachta" and is native to India, Bangladesh and Pakistan, growing in tropical and semi-tropical regions. Other names include dogonyaro, vimba and kohomba (Ganguli, 2003). It is an evergreen tree, cultivated in various parts of the world. Every part of the tree has been used as traditional medicine for house hold remedy against various human ailments from antiquity (Koul et al., 1990). Azadirachta indica is widely used as native medicine in the treatment of typhoid fever. In Nigeria, indigenous traditional healers use the prepared decoctions (extracts of the leaves in water), as folklore anti-malaria. These preparations when taken orally in single or multiple doses have been very helpful in the treatment of fevers caused by malaria. Neem is also used for treating acne; it effectively kills the bacteria that give birth to acne. It reduces inflammation caused by acne. Other benefits of neem are as follows: It cures general skin problems like dandruff, dry skin, wrinkles, itchy scalp and skin ulcers (Cletus and Justina, 2007)

Vernonia amygdalina (Bitter leaf) is one of the widely studied medicinal plants. It belongs to the family "compositae". It occurs as a small shrub with height from $2-5 \mathrm{~m}$, the stem is rough with young branches and petiolate green leaves of about $6 \mathrm{~mm}$ diameter. The leaves are obvare or elliptic in shape, short acuminate at the apex and slight chordate at the base. The bitter taste of the plant leaves gives rise to its common name "Bitter Leaf' (Nwobegu and Egbuna, 2002). The genus was named in honour of an English botanist, William Vernon. It is used in Nigerian folk medicine as a tonic and remedy against constipation, fever, high blood pressure and many infectious diseases. The stem and root divested of the bark are used as chew-sticks in Nigeria (Taiwo et al., 1999). All parts of the plant are pharmacologically useful. The roots and leaves are used in the treatment of fever, malaria, diarrhea, dysentery, kidney problems, and stomach discomfort among several other uses (Iwalokun et al., 2006). In many parts of Africa, bitter leaf is prepared and eaten like spinach. The roots and twigs are chewed as appetizers. This herb is believed to have tonic, anti-parasitic, anti-tumor, and anti-bacterial 
properties (Erasto and Grierson, 2007). Components of the alcoholic extracts of leaves and seeds are effective against both chloroquine resistant and sensitive strains of malaria parasite. Aqueous leaf extract from Vernonia amygdalina also elicited an enhanced anti-malarial effect of chloroquine in mice infected with chloroquine resistant and sensitive Plasmodium berghei strains (Iwalokun, 2008).

In view of the above - mentioned facts, there is a need to conduct further biochemical studies on both Vernonia amygdalina and Azadirachta indica to elucidate their comparative potentials. This work was aimed at investigating the comparative effects of their ethanol leaf-extracts on catalases and reduced glutathione in albino rats.

\section{MATERIALS}

\section{Materials And Methods}

Fresh leaves of Vernonia amygdalina and Azadirachta indica were collected from Abakaliki in Ebonyi State. Forty-two male albino rats were obtained from University of Nigeria, Nsukka. All the chemicals and reagents used were of analytical standard.

\section{METHODS.}

\section{Extraction of the plant material.}

About $900 \mathrm{~g}$ of dried and ground Vernonia amygdalina and Azadirachta indica leaves were each soaked into $1700 \mathrm{ml}$ of ethanol for 24 hours. The solution of the extract was gotten after several squeezing and filtrations into a graduated beaker and allowed to dry under mild sunlight until a semi-solid extract was gotten.

\section{Administration of plant extract}

Leaf-extracts of Azadirachta indica at 200,400 and $600 \mathrm{mg} / \mathrm{kg}$ of body weights were administered for two weeks to animals in groups $\mathrm{A}, \mathrm{B}$ and $\mathrm{C}$ respectively, with corresponding concentrations of Vernonia amygdalina leaf-extract given to animals in groups D, E, and F, through oral intubation, while those in group $\mathrm{G}$ served as the control.

\section{Blood sample collection.}

The blood samples were collected on the fifteenth day through heart puncture into labeled sterile specimen containers.

\section{Enzyme assay}

Catalase activities were determined through the methods of Boon et al. (2007) and Arun et al. (2002) while reduced glutathione levels were assayed by the method of Pastore et al., 2003.

\section{Results}

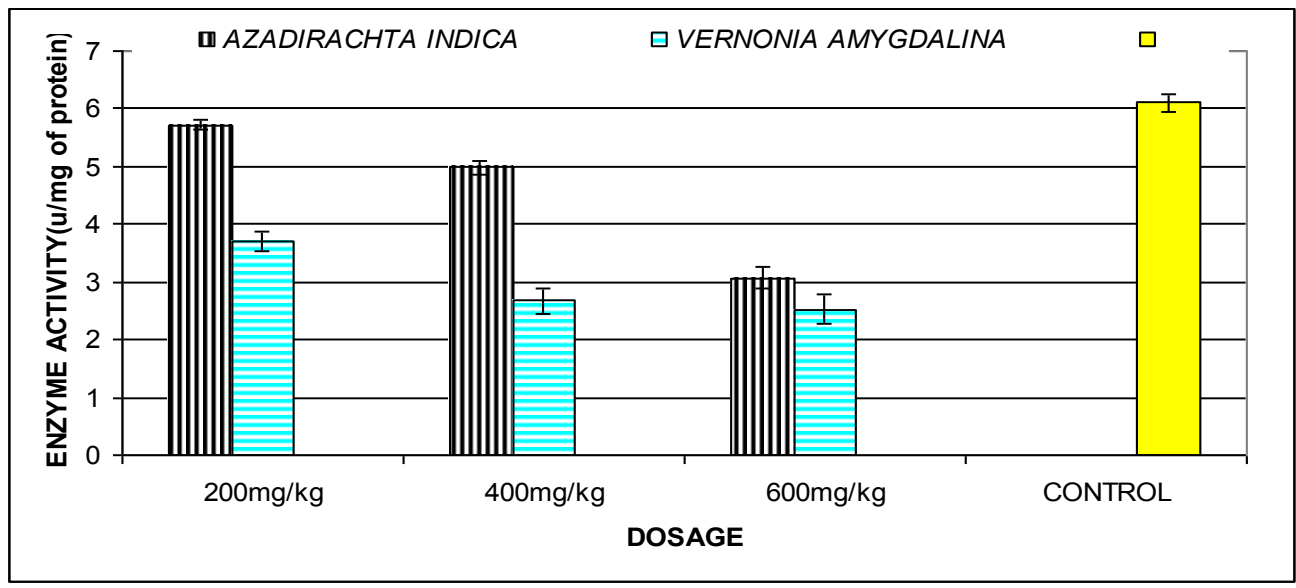

Fig.1: Catalase Activities (u/mg of protein). 


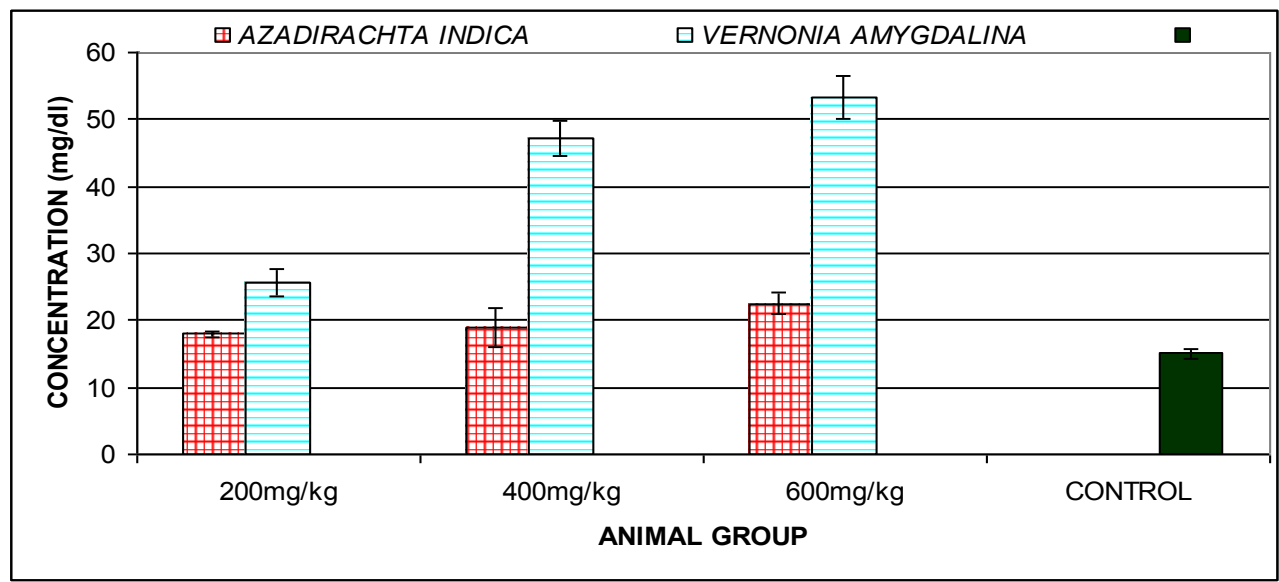

Fig. 2: Reduced Glutathione Concentrations (mg/dl).

\section{Discussion And Conclusion}

At $200 \mathrm{mg} / \mathrm{kg}$, the leaf-extract from Azadirachta indica did not show any significant reduction while that of Vernonia amygdalina showed significantly greater reductions of catalase activities even at all the stipulated doses (Fig. 1). This result was also found to be consistent with the findings of Whitney and Hamilton (1990) who reported the presence of oxalate and phytate in plant extracts which are potent inhibitors of catalase. Kaushaiya et al. (1988) reported also that vegetables contain some levels of anti-nutrients and toxic substances such as alkaloids, phytate, cyanide, nitrates and oxalates, some of which inactivate catalases. Any heavy metal ion (such as copper cations in copper (II) sulfate) will act as a non-competitive inhibitor on catalase. Harish (2009) reviewed that the aqueous extract from neem reduced the catalase activities.

Glutathione, a major non-protein thiol in living organisms, plays a central role in coordinating the body's antioxidant defense processes. Reduced thiols have long been reported to be essential for recycling of antioxidants like vitamin E and vitamin C. Administration of thiol compounds such as glutathione, cysteine and methionine have been shown to protect against oxidative stress in humans and animals (Constantinescu et al., 1993). Both extracts increased glutathione concentrations significantly though the extract from Azadirachta indica did not show any significant increase at $200 \mathrm{mg} / \mathrm{kg}$ (Fig. 2). Reduced glutathione concentration was found to be significantly higher $(\mathrm{P}<0.05)$ in the treated animals and Vernonia amygdalina proved more effective. This could be attributed to the reduction in catalase activity, in order to prevent cell damage since free radicals are constantly produced by aerobic cells. This is in line with the information given by Murray et al. (2006) that cellular damage through oxidation of proteins, DNA and lipids may result if free radicals accumulate in the cell. Yoshikawa et al. (1993) have shown that indomethacin induced gastric mucosal injury decreased the glutathione peroxidase activity and aggravated the injury due to accelerated accumulation of $\mathrm{H}_{2} \mathrm{O}_{2}$ and lipid peroxidation. Furthermore, excessive peroxidation causes increased glutathione consumption (Banerjee et al., 1994)

Oxidative stress, defined as a disruption of the balance between oxidative and antioxidative processes, plays an important role in the pathogenesis of atherosclerosis (Yokozawa et al., 2006). A cholesterol rich diet results in increased lipid peroxidation followed by hypercholesterolemia (Adaramoye et al., 2005). These observations suggest that the ethanol leaf-extract of Vernonia amygdalina was more effective as an antioxidant agent than that of Azadirachta indica.

\section{References}

[1]. Adaramoye, O. A., Nwaneri, V.O., Anyanwu, K. C. (2005). Possible anti-atherogenic effect of kolaviron (a Garcinia kola seed extract) in hypercholesterolemic rats. Clinical Experimental Pharmacology and Physiology, 32; 40-46.

[2]. Andrews, D.S. and Fatt, C. (2002). The typical evergreen plant of India "Dogonyaro". Journal of Biological Science, 61; $34-40$.

[3]. Arun, R., Susri, R.C., Biswajit, M. and Sandip, K. B. (2002). Antioxidant activity of ethanol extract of rhizome of Picrorhiza kurroa on indomethacin induced gastric ulcer during healing. Indian Journal of Clinical Biochemistry, 17 (2); $44-51$.

[4]. Banerjee, S., Hawks, C., Miller, S., Dahill, S., Beattie, D. V. and McColl, K. E. I. (1994). Effect of Helicobacter pylori and its eradication on gastric juice ascorbic acid. Gut, 35; 317-322.

[5]. Bergman, K. N. (2000) Regulation of cholesterol biosynthesis. Journal of Cholesterolemia, 3: 220-224.

[6]. Boon, E.M., Downs, A. and Marcey, D. (2007). Catalase hydrogen peroxide, hydrogen peroxide oxidoreductase, catalase structural intorial text. Johnson publications, London. 32-71.

[7]. Cletus, N.A., and Justina, E.O. (2007). A Handbook of pharmacology for nursing and allied health profession. $2^{\text {nd }}$ edition. AfricanFep publishers Ltd, Nigeria. 29-108.

[8]. Constantinescu, A., Han, D. and Packer, L. (1993). Vitamin E recycling in human erythrocyte membrane. Journal of Biology and Chemistry, 268; 10906- 10913.

[9]. Erasto P. and Grierson, D. S. (2007). Evaluation of anti-oxidant activity and the fatty acid profile of the leaves of Vernonia amygdalina growing in South Africa. Journal of Food Chemistry, 10; 636 - 642

[10]. Ganguli, S. (2003). Neem: A therapeutic for all season. Journal of Current Science Leaves and Flowers, $11 ; 4-11$. 
[11]. Harish, K.G. (2009). The effect of neem in rats. Journal of Biological Chemistry, 32; 42- 46.

[12]. Iwalokun, B.A. (2008). Enhanced antimalarial effect of chloroquine by aqueous Vernonia amygdalina leaf extract in mice infected with chloroquine resistant and sensitive Plasmodium berghei strains. African Health Science, 8(1); $25-35$.

[13]. Iwalokun, B.A., Efedede, B.U., Alabi-Sofunde, J.A., Oduala, T. and Akinwande, A.I. (2006). Hepatoprotective and antioxidant activities of Vernonia amygdalina on acetaminophen-induced hepatic damage in mice. Journal of Medicinal Food, 9; 524-530.

[14]. Kaushaiye, E.J., Cannon, H.L. and Underwood, H.W. (1988). Toxicants occurring naturally in foods. $5^{\text {th }}$ edition, National academy of sciences press, Washington D.C. 43-87.

[15]. Koul, O., Isman, M.B and Ketkar, C.M. (1990). Traditional medicine for household remedy. Canadian Journal of Botany, 68; 1 11.

[16]. Murray, R. K. Granner, D. K, and Rodwell, V.W. (2006). Harper's illustrated Biochemistry. $27^{\text {th }}$ edition, McGraw Hill education, Asia. $400-500$

[17]. Nwobegu, J. S. and Egbuna P. A. C., (2002). Antihepatotoxicity of crude extract of Vernonia amygdalina on rat's liver. Research work submitted to the department of Biochemistry, University of Nigeria, Nsukka. 3-15.

[18]. Pastore, A., Piemonte, F., Locatelli, M., Lo Russo, A., Gaeta, L.M., Tozzi, G. and Federici, G., (2003). Determination of blood totally reduced and oxidized gluthatione in paediatric subjects. Clinical Chemistry, 47 (8); 1467-1469.

[19]. Taiwo, O., Xu, H.X. and Lee, S.F. (1999). Antibacterial activities of extracts from Nigerian chewing sticks, Phytotherapy Re search, $13(8) ; 675-679$.

[20]. Whitney, E.N. and Hamilton, E.M. (1990). Vegetables, understanding nutrition. $5^{\text {th }}$ edition, St. Paul, U.S.A. 43.

[21]. Yokozawa, T., Cho, E.J. and Sasaki, S. (2006). The protective role of Chinese prescription - Kangen-karyu extract on diet-induced hypercholesterolemia in rats. Biology and Pharmacology Bulletin, 29; 760-765.

[22]. Yoshikawa, T., Nioto, Y., Kishi, A., Tomii, T., Kaneko, T., Linuma, S., Ichikawa, H., Yasuda, M., Takahashi, S. and Kondo, M. (1993).Role of active oxygen, lipid peroxidation and antioxidants in the pathogenesis of gastric mucosal injury induced by indomethacin in rats. Gut, 34; 732-737 